\title{
EHMTI-0377. The influence of genetic constitution on migraine drug responses
}

\author{
AF Christensen ${ }^{1 *}$, AL Esserlind ${ }^{1}$, T Werge $^{2}$, H Stefansson $^{3}$, J Olesen ${ }^{1}$ \\ From 4th European Headache and Migraine Trust International Congress: EHMTIC 2014 \\ Copenhagen, Denmark. 18-21 September 2014
}

\section{Background}

Specific acute treatments of migraine are $5 \mathrm{HT} 1 \mathrm{~B} / \mathrm{D}$ receptor agonists, i.e. triptans and ergotamine. No migraine prophylactic drugs are specific to migraine. Prophylactic drugs are selected by time consuming "trial and error". Personalized treatment is therefore much needed.

\section{Aim}

The objective of this study was to test the effect of 12 common SNPs significantly associated with migraine on migraine drug responses.

\section{Methods}

Semi-structured migraine interviews, blood samples and genotyping were performed on 1806 unrelated migraine cases recruited from the Danish Headache Center. Association analyses were carried out using logistic regression and ORs were calculated assuming an additive model for risk. The effect on drug responses was tested for a combined genetic score and for each of the 12 SNPs.

\section{Results}

A higher combined genetic score, and a single SNP, rs2651899 in PRDM16, were significantly associated with efficacy of triptans with an OR of success of 2.6 and 1.3, respectively. A number of SNPs showed nominal preferential association with the efficacy of triptans and others with prophylactic drugs.

\section{Conclusion}

We show for the first time an association between genetic constitution and migraine drug response. This is a first step towards future individualized medicine.

No conflict of interest.

'Dep. of Neurology Glostrup University Hospital University of Copenhagen, Danish Headache Center, Copenhagen, Denmark

Full list of author information is available at the end of the article

\section{Authors' details}

'Dep. of Neurology Glostrup University Hospital University of Copenhagen, Danish Headache Center, Copenhagen, Denmark. ${ }^{2}$ Mental Health Center Sct. Hans University of Copenhagen, Institute of Biological Psychiatry, Roskilde, Denmark. ${ }^{3}$ Sturlugata 8, deCODE Genetics, Reykjavik, Iceland.

Published: 18 September 2014

doi:10.1186/1129-2377-15-S1-M3

Cite this article as: Christensen et al:: EHMTI-0377. The influence of genetic constitution on migraine drug responses. The Journal of Headache and Pain 2014 15(Suppl 1):M3.

\section{SpringerOpen ${ }^{\odot}$}

(C) 2014 Christensen et al; licensee Springer. This is an Open Access article distributed under the terms of the Creative Commons Attribution License (http://creativecommons.org/licenses/by/2.0), which permits unrestricted use, distribution, and reproduction in any medium, provided the original work is properly cited.
Submit your manuscript to a SpringerOpen ${ }^{\circ}$ journal and benefit from:

- Convenient online submission

- Rigorous peer review

- Immediate publication on acceptance

- Open access: articles freely available online

- High visibility within the field

Retaining the copyright to your article

Submit your next manuscript at $>$ springeropen.com 